\title{
Embracing Green Technology Innovation Through Strategic Human Resource Management: A Case of an Automotive Company
}

\author{
${ }^{1}$ Reihaneh Montazeri Shatouri, ${ }^{2}$ Rosmini Omar, ${ }^{3}$ Kunio Igusa and ${ }^{4}$ de São Pedro Filho, Flávio \\ ${ }^{1,2}$ International Business School, Universiti Teknologi Malaysia, Kuala Lumpur, Malaysia \\ ${ }^{3}$ College of Asia Pacific Management, Ritsumeikan Asia Pacific University, Beppu, Oita, Japan \\ ${ }^{4}$ Post Graduation Programme in Administration, Foundation Federal University of Rondônia, Porto Velho, Rondônia, Brazil
}

Received 2013-10-03; Revised 2013-12-06; Accepted 2013-10-10

\begin{abstract}
What makes a technological innovation successful for an industry? This study examines how green technology innovation is impacted by strategic management of the human resource in firms. The value of this study lies in its intention to explain the needs to effectively blend people matters first before endeavouring technologies. We focus on Malaysia's leading automobile manufacturer, Proton which currently embarks on smart green initiatives in its product development. The quantitative survey identifies potential challenges of Proton's human resource management that may infringe green technology process. Our findings confirm the effects of strategic human resource management system on adopting the green technology innovation. The most important factors affecting the implementation of green technology include knowledge application, team development, knowledge sharing, performance-based reward and training of before and during the process of embracing the new technology.
\end{abstract}

Keywords: Automotive Industry, Green Technology, Innovation, Proton, Strategic Human Resource Management

\section{INTRODUCTION}

It seems not so long ago that the world community has comprehended not pursuing technology advancement. There are arguments that such development will result in a long-term degradation and possibly irreversible damage to the natural environment and human health (Nunes and Bennett, 2008).

However, Schumpeter, in 1947, relates technology advancement to innovation that generates benefits for societies. In contrast to degradation, innovation is historical and non-reversible changes that not only defines changes in production function, economic growth and industrial dynamics, but also should be able to generate improved social conditions when the innovation reaches critical mass (Dinopoulos, 2006).
Firms can imitate and innovate, while productivity and social improvement is the premier aim of an innovative process.

Series of innovation in the automotive industry reflect this Schumpeterian model. When car usage is widely claimed to result in a broad range of air emissions causing climate change, smog, green house gases and human diseases (Frenken et al., 2004), green solutions and environmental protection rises as necessities in the 21 st century (ZTE, 2011).

In recent decades, many automakers have embarked on green technology initiatives to gain competitive advantage in the global market (Montazeri and Wan, 2011). Several famous automobile manufacturers such as Toyota, Volkswagen (VW), Honda, General Motors (GM), Ford, BMW and Mercedes Benz are in close

Corresponding Author: Reihaneh Montazeri Shatouri, International Business School, Universiti Teknologi Malaysia, Kuala Lumpur, Malaysia 
competition with each other in producing green cars. However, sophisticated technologies and innovative manufacturing practices would only enhance operational performance a little, unless the Human Resource Management (HRM) practices are in place to form a consistent socio-technical system (Chen and Huang, 2007). Successful pioneering automakers have invested funds into new technologies and equipment. Over and above that, they have also harnessed their human resources potentials, provided world-class skills and training to their workforces and winning new markets (Laforet, 2007).

This study is based on an in-depth study of Proton Holdings Berhad as the first automaker in Malaysia's commercial vehicle industry. Proton is the pioneer of Malaysia's automobile engineering. Yet, its strengths in competing with major automakers in research and development require more innovative thinking. For future development, it has started to embark on green technology innovation. Our main research inquiry concerns on whether the employees in Proton ready to uptake and embrace the green innovation?

\section{LITERATURE REVIEW}

\subsection{Research and Development (R\&D) and Green-Pollution Reduction Technologies}

Since automotive industry is one of the main consumers of fossil fuels, implementing green technology has become an inevitable choice for environmental sustainability. Increasing consumer awareness about the harmful effects of vehicles exhaust emissions has forced auto manufacturers for technological improvements to produce green products. Moreover, the increasing role of states and local governments in prevention and control of air pollution have gradually led to the adoption of green innovations (Pollack, 1968; USEPA, 2010).

Survival in the fast-changing global market has enforced technology-based companies to adjust their R\&D structures, processes and systems to meet the socio-economic development demands. Research and development as an engine for modernization and strategic trajectory towards growth have been one of the major sources of productivity growth over decades (Castells, 1999). In the early 21st century, decarburizing transport is proving to be a large $R \& D$ project. Initially in reaction to the oil shocks and concerns over urban air pollution, the development of alternative fuels to petrol and diesel has been ongoing since the 1970s. Today, low-carbon technologies are quickly advancing with petrol and diesel hybrids, battery electric and hydrogen fuel cell by nearly every main auto manufacturer. Concerns about up-scaling production and the environmental and social costs of biofuels imply that electricity and hydrogen will be broadly regarded as the sustainable transport fuels of the future (Pollet et al., 2011).

The strategic orientation of automotive $R \& D$ reflects the industry's mission to incorporate sustainability into all future activities directly from the outset and then it can build a competitive advantage for the economy, contribute to social welfare and protect the ecosystems. To develop secure and sustainable products, which are affordable within the global market, the automotive industry has been highly active for over a decade, participating in a wide range of collaborative $R \& D$ projects. The execution of $\mathrm{R} \& \mathrm{D}$ recommendations is intended to satisfy socio-economic demands for mobility and transport in the future while enhancing the competitiveness of the automotive industry. In this respect, R\&D as a key success factor towards technological development must operate based on an appropriate approach (Tavakkoli-Moghaddam et al., 2006). In this respect, human resources have the most important function in decision-making process concerning R\&D projects that performance and results strongly depend on human capabilities. In R\&D department that several projects may have to be implemented simultaneously by a limited number of human workforces, professional labours with different skills play an essential role in successful creations of innovative products. Furthermore, it is crucial to proactively act upon all salient business issues at the early stage in R\&D process. Firms need to ensure that concepts and developments are drive dynamism in the markets at the later stages. In this way, the transition towards mass flexibility, the increasing heterogeneity of the automobile market and the penetration of foreign investment have been considered as important factors behind the success of corporations operating in multiple regions of the world (Miller, 1994).

\subsection{Proton Holdings Berhad-Company Description}

Perusahaan Otomobil Nasional (PROTON) is the Malaysia's leading automobile manufacturer incorporated in 1983 to manufacture, assemble and sell motor vehicles and related products, including accessories, spare parts and other components. The 
company produced Malaysia's first car, Proton Saga and commercially launched in 1985. The company, which has been held under the government's investment arm Khazanah Nasional, recently sold to local conglomerate DRB-Hicom Holdings. At RM5.50 per share, Khazanah has sealed a deal with DRBHicom to sell its 42.7 percent stake in Proton for a total of RM1.28 billion to boost liquidity in the local stock market and monetize assets. DRB-Hicom's proposed strategy and business plan provide an effective platform to enhance Proton's sustainability and meet its long-term growth goals (PHB, 2011).

\subsection{Green Technology Innovation in Proton}

With the rapid pace of technological changes, auto manufacturers encourage to adopt new technologies in line with the global competition. In this respect, Proton regularly needs to update its directions into the philosophy of new automotive business trends. It has addressed this issue with the formation of strategic plans based on Kaizen concept, which is centered on practices that focus upon continuous improvement of the processes in manufacturing, engineering, product development and business management (PHB, 2011).

The Proton Technology Roadmap (PTR) applies as a blueprint for the company in shaping Proton's car of the future. It constitutes an integral part of the decision making process of the technologies that must be acquired in order to remain competitive and profitable in the domestic and global market. Proton's pillar of PTR is mostly based on body, chassis, safety, electrical, electronic, powertrain and alternative powertrain.

Proton dedicates itself to the development of green technology innovation in line with the government's initiative to make Malaysia a regional hub for ecofriendly vehicles. Although, in comparison with global OEMs (Original Equipment Manufacturers), Proton is a relatively smaller company which has not much allocated into investment in green technology, it has made a great step towards upgrading its engineering capabilities with the acquisition of Lotus Group International Limited (PHB, 2011).

Lotus Engineering has been granted many contracts by major OEMs to design and engineer various ecofriendly vehicle demonstrators. The breadth of Lotus is significantly focused on the four core competencies, lightweight architectures, driving dynamics, efficient performance and electric and electronic integration. Then, in 2010, Proton unveiled the EMAS concept cars at the prestigious Geneva Motor show, which was designed by Giugiaro's ItalDesign and built in collaboration with Lotus Engineering to celebrate the Malaysian car manufacturer's 25th anniversary. EMAS that is a symbol of Eco Mobility Advance Solution records the commencement of Proton's global small car feasibility study. EMAS is not only a concept car but also is the physical incorporation of the pride, passion and progress that is a snippet of the company's dreams in terms of concept, styling, design and technology (PHB, 2011).

\section{CONCEPTUAL FRAMEWORK}

Green innovations can effectively happen, if companies have the right people with the right skills and competencies. Innovation driven by leaders who focus on human capital, company's culture and strategic planning opens door for a proactive strategic posture, reflected by flexible organizational structure (Laforet, 2007). Nevertheless, implementation of corporate green management initiatives needs a high level of technical and management skills among employees.

A strategic HR management system plays a significant role in creating an organizational culture that promotes green technology innovation. Organizational culture has a direct impact on firm innovativeness and contributes to a higher level of innovation and new product development. Thus, it can be conceptualized that organizational culture serves as the mediator between the strategic HR management system and innovativeness in green technology (Deming, 2000). Furthermore, there is a positive relationship between knowledge management and green innovation (Chen and Huang, 2007). Figure 1 illustrates a conceptual framework for innovativeness in green technology at the automotive industry by applying a deliberate strategic HR management system and knowledge management with the intervening factors, organizational culture, knowledge application and knowledge sharing.

As human resources has proven to assist on the improvement of business performance, all businesses could embrace green innovations while deliberately manage their human capitals (Chen and Huang, 2007). There are three sets of HR practices that support an innovation-oriented HR system. They include, (1) training-focused that concentrates on human resource investment and skills enhancement, (2) performancebased reward that emphasizes on rewarding employees' contributions and (3) team development that centers on development and fulfillment of teambased activities (Lau and Ngo, 2004). 


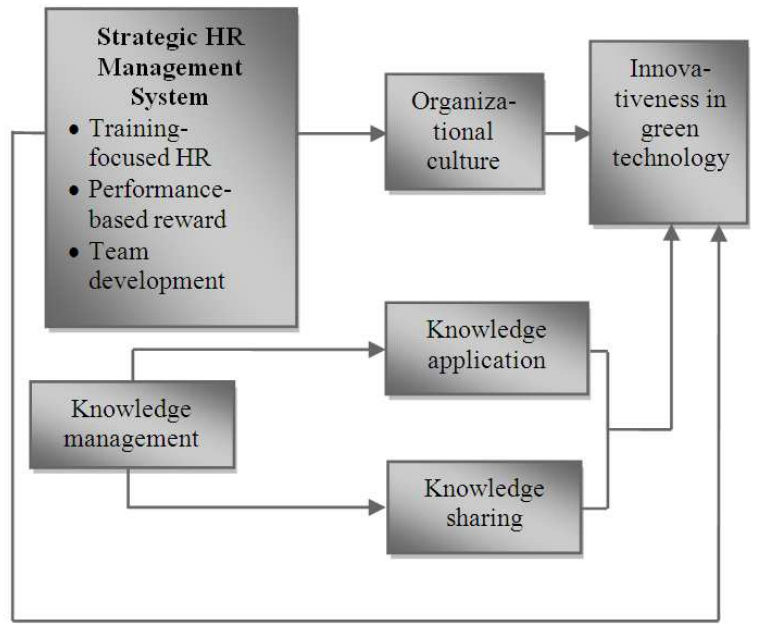

Fig. 1. Conceptual framework Source: Chen and Huang (2007); Deming (2000)

Knowledge and skills that acquired through formal education or previous training will depreciate and become outmode, so workers need consistent engagement and ongoing process of skills acquisition (Remmen and Lorentzen, 2000). Training enhances employees' knowledge and skills that are crucial to new product development. High performing organizations spend more time on education and training, not only on technical task related skills but also on communication and teamwork abilities. To achieve organizational effectiveness, HR trainings must be congruent with the firm strategy and work processes. Training provides the opportunity for individuals and organizations to develop appropriate competencies.

Nevertheless, to sustain competitiveness, learning behaviors have to be rewarded especially when individual performance has improved. Performancebased payment is often found in HR systems that would support innovation. HR system with performancelinked rewards has positive effects on company performance mediated by employees' skills, attitudes and behaviors. Performance-based reward can represent a commitment to employees, provide incentives for creativity and subsequently reinforce innovative performance. In the study of innovative product development, performance-based reward has been considered as a significant compensation tool. Many innovation-oriented firms focus on various compensation packages to reward total quality management and employee involvement (Deming, 2000).
Numerous technology-based studies (Lado and Wilson, 1994; McMahan et al., 1999; Muffatto, 1998) revealed that committing to team development is essential for the success of innovation-oriented firms. Team development planning is a core necessity to organizational development as it has a high impact on the firm's performance and boosts staff morale, productivity and innovativeness. On the other hand, team cooperation, effective communication and conflict resolution are important aspects in teams with an innovation expectation (Deming, 2000). Toward a socialcontext theory of human resource management, organizational culture locates as an antecedent of employee attitudes and behaviors. A strategically proactive human resources creates a corporate culture of innovation and creativity that is necessary for executing business strategies. However, there is a necessity to develop a technology-based culture in order to create competitive advantage in technology-intensive industries. Only with an innovation culture that involves taking risks, creativity, teamwork, quality focus and effective production system, a company can be competitive in new product development.

Moreover, implementation of Kaizen as a system based on making little changes on a regular basis that always improves productivity, safety and effectiveness while reduce waste, is essential to manufacture high quality products. To promote this type of culture, firms must develop employees through constant learning, teamwork, autonomy and an inclination towards technological innovation. The system that consciously plans to alter employees' schemas towards innovation would result in an innovative culture. It follows that organizational culture is an intervening element between strategic HR management system and firm innovativeness (Deming, 2000).

Furthermore, innovation initiatives depend excessively on employees' knowledge, expertise and commitment as key inputs in the value creation process (Hodgetts and Hegar, 2007). Since companies enable to access the knowledge and expertise of the employees, they may require good capacities to exploit human knowledge management to ensure effective utilization of the human resource in achieving the organizational goals (Sudin, 2011). In recent years, many of the most profitable companies have been those that have successfully managed knowledge workers (Hodgetts and Hegar, 2007). Once a company has established its direction, it must create an environment to develop 
knowledge application and knowledge sharing culture. The knowledge-based viewpoint considers firms as repositories of knowledge and competencies. Hence, knowledge and competencies of human resources are recognized as valuable assets of the firm because of their characteristics. Knowledge-based resources are socially complex and usually difficult to imitate, so diverse knowledge bases and competencies of the firms are the main determinants of sustained competitive advantage and superior corporate performance (Chen and Huang, 2007). We integrate the strengths of these past studies and develop a conceptual framework as below.

\section{METHODOLOGY AND PROCEDURE}

Based on the conceptual framework, we develop a survey questionnaire for Proton manufacturing plant in Shah Alam, Malaysia. The questionnaire was in a web and paper-based form. We opted for a convenience sample, encompassing employees who were engaged in green technology program in Proton, Malaysia. Before the actual data collection period, we conducted a pilot study was conducted of 30 employees to assess the validity of the research instrument and test its reliability and internal consistency. We gained a total of 107 completed questionnaires from different departments of Proton. This quantitative phase helped us to identify limitations of Proton's human resource management as it embarked on green technology initiatives.

\section{FINDINGS AND DISCUSSION- QUANTITATIVE PHASE}

The findings invokes the fact that implementation of green technology requires consistent focus towards quality assurance and innovation as core values and strong teamwork between employees and management. Factors affecting the outcome of the green process improvement may include process inputs such as training, performancebased reward, team development, organizational culture and knowledge management. Table 1 describes the variables defined and measured within the study.

The variables and measurements applied in this study are shown in Table 2.

Table 3 offers the mean test of the variables included in this study, as we generate the rank order.

Table 4 discloses the most important factor influenced implementation of green technology in Proton. It is "Practice quality circles". This factor has been followed by "Consider innovation as a core value" and "Practice teamwork" with mean value of 3.93 and 3.91, respectively. However, the two least influential points are the "Programs on management of the green systems technology" and "A large salary difference between high and low performers of green technology" with the mean value of 2.5 and 1.94 , respectively.

$\underline{\text { Table 1. Description of measured variables }}$

\begin{tabular}{|c|c|c|}
\hline No. & Variable & Description \\
\hline 1. & Training & $\begin{array}{l}\text { A continuous systematic company-wide and divisional training program to update employees' } \\
\text { knowledge with the latest technologies } \\
\text { - Aimed at increasing employees' environmental awareness and development of new technical and } \\
\text { management competencies and innovative capabilities } \\
\text { - Focused on both technical, task related skills and communication and team working abilities } \\
\text { - Emphasized on on-the-job training (OJT) to ensure that employees can fully utilize their abilities } \\
\text { in their work }\end{array}$ \\
\hline 2. & $\begin{array}{l}\text { Performance- } \\
\text { based reward }\end{array}$ & $\begin{array}{l}\text { Extrinsic and intrinsic rewards with an emphasis on outcomes-based rewards to increase } \\
\text { engagement and participation in employees }\end{array}$ \\
\hline 3. & $\begin{array}{l}\text { Team } \\
\text { development }\end{array}$ & $\begin{array}{l}\text { Development and fulfilment of team-based activities to encourage creative thinking and develop a } \\
\text { variety of interpersonal expertises including communication, leadership and motivational skills }\end{array}$ \\
\hline 4. & $\begin{array}{l}\text { Organizational } \\
\text { culture }\end{array}$ & $\begin{array}{l}\text { Employees' values, attitudes and behaviours that are taught to the organizational members as a } \\
\text { way of perceiving and thinking }\end{array}$ \\
\hline 5. & $\begin{array}{l}\text { Knowledge } \\
\text { management }\end{array}$ & $\begin{array}{l}\text { The process of capturing, distributing and effectively using knowledge and skills that may affect } \\
\text { productivity, efficiency, innovativeness and financial performance }\end{array}$ \\
\hline 6. & $\begin{array}{l}\text { Innovativeness in } \\
\text { green technology }\end{array}$ & $\begin{array}{l}\text { Innovation in the products, processes, or in the business model that develop the firm to higher } \\
\text { levels of environmental sustainability. It would be a simply solution that combine economy and } \\
\text { ecology by economizing resources in a smarter way }\end{array}$ \\
\hline
\end{tabular}


Table 2. Variables

\begin{tabular}{|c|c|c|}
\hline No. & Variable & Variable measure \\
\hline \multirow[t]{5}{*}{1.} & Training & 1.1 Green technology programs \\
\hline & & 1.2 green technology workshops for new hires \\
\hline & & 1.3 Programs to help in doing green innovations \\
\hline & & 1.4 Course on innovation policies \\
\hline & & 1.5 Programs on management of the green systems technology \\
\hline \multirow[t]{6}{*}{2.} & Performance- & 2.1 Individuals' contribution in green technology implementation \\
\hline & based Reward & 2.2 A large salary difference between high and low performers of green technology. \\
\hline & & 2.3 Reward for initiate, develop and implement green concepts \\
\hline & & 2.4 Results-based appraisal policy \\
\hline & & 2.5 Behaviour-based appraisal policy \\
\hline & & 2.6 Employees' development in applying green technology \\
\hline \multirow[t]{6}{*}{3.} & Team Development & 3.1 Practice teamwork \\
\hline & & 3.2 Practice problem-solving \\
\hline & & 3.3 Practice quality circles \\
\hline & & 3.4 Practice quality improvement teams \\
\hline & & 3.5 Practice leadership training \\
\hline & & 3.6 Practice teamwork on initiating a new green concept car \\
\hline \multirow[t]{9}{*}{4.} & Organizational Culture & 4.1 A dynamic and entrepreneurial firm \\
\hline & & 4.2 Growth and acquiring new resources \\
\hline & & 4.3 Employees' chance to offer their feedback to management officials \\
\hline & & 4.4 Encourage employees' suggestions on performance improvement \\
\hline & & 4.5 Encourage trying new methods by employees \\
\hline & & 4.6 Allow employees to make decisions \\
\hline & & 4.7 Value employees' voices \\
\hline & & 4.8 Conduct surveys to compare the compensation policies fair against competitors' \\
\hline & & 4.9 A significant role of CEO in reducing hazardous pollutants \\
\hline \multirow[t]{7}{*}{5.} & Knowledge Management & 5.1 Knowledge Sharing \\
\hline & & 5.1.1 Knowledge sharing regarding green technology between supervisors and subordinates \\
\hline & & 5.1.2 Knowledge sharing regarding green technology among colleagues \\
\hline & & 5.1.3 Knowledge sharing regarding green technology among departments \\
\hline & & 5.2 Knowledge Application \\
\hline & & 5.2.1 Effectively manage knowledge of innovative green technologies into practical use \\
\hline & & 5.2.2 Effectively utilize knowledge of innovative green technologies into practical use \\
\hline \multirow[t]{8}{*}{6.} & Innovativeness in & 6.1 Disseminate the innovation message throughout the company \\
\hline & Green Technology & 6.2 Firm's innovation vision aligned with projects platforms \\
\hline & & 6.3 Consider innovation as a core value \\
\hline & & 6.4 Articulate a coherent set of innovation objectives by senior managers \\
\hline & & 6.5 Metrics to measure the effectiveness of innovation initiatives \\
\hline & & 6.6 Allocate adequate resources to exploring and implementing innovative ideas \\
\hline & & 6.7 An entrepreneur, innovative and risk taker CEO \\
\hline & & 6.8 Company's commitment to innovation and development \\
\hline
\end{tabular}

Table 3. Mean test

\begin{tabular}{lll}
\hline Variable & $\mathrm{N}$ & Mean \\
\hline Training & 107 & 2.8056 \\
Performance-based reward & 107 & 2.6994 \\
Team development & 107 & 3.7680 \\
Organizational culture & 107 & 3.3844 \\
Knowledge sharing & 107 & 3.1183 \\
Knowledge application & 107 & 3.4019 \\
Innovativeness & 107 & 3.5304 \\
\hline
\end{tabular}


Table 4. Variables' measure

\begin{tabular}{|c|c|c|c|}
\hline Variable measure & Mean & $\mathrm{N}$ & Std. Deviation \\
\hline Practice quality circles & 4.16 & 107 & 0.837 \\
\hline Consider innovation as a core value & 3.93 & 107 & 1.025 \\
\hline Practice teamwork & 3.91 & 107 & 0.937 \\
\hline Practice quality improvement teams & 3.80 & 107 & 0.946 \\
\hline Practice problem-solving & 3.79 & 107 & 0.952 \\
\hline Practice leadership training & 3.69 & 107 & 0.975 \\
\hline Company's commitment to innovation and development & 3.69 & 107 & 1.085 \\
\hline Employees' chance to offer their feedback to management officials & 3.67 & 107 & 0.786 \\
\hline Growth and acquiring new resources & 3.63 & 107 & 0.917 \\
\hline Articulate a coherent set of innovation objectives by senior managers & 3.62 & 107 & 0.843 \\
\hline A dynamic and entrepreneurial firm & 3.57 & 107 & 0.715 \\
\hline Firm's innovation vision aligned with projects platforms & 3.53 & 107 & 1.022 \\
\hline An entrepreneur, innovative and risk taker CEO & 3.52 & 107 & 1.152 \\
\hline Allocate adequate resources to exploring and implementing innovative ideas & 3.48 & 107 & 0.817 \\
\hline A significant role of CEO in reducing hazardous pollutants & 3.45 & 107 & 0.871 \\
\hline Effectively manages knowledge of innovative green technologies into practical use & 3.45 & 107 & 0.804 \\
\hline Encourage trying new methods by employees & 3.44 & 107 & 1.039 \\
\hline Encourage employees' suggestions on performance improvement & 3.41 & 107 & 1.064 \\
\hline Disseminate the innovation message throughout the company & 3.41 & 107 & 0.824 \\
\hline Effectively utilizes knowledge of innovative green technologies into practical use & 3.36 & 107 & 0.690 \\
\hline Practice team work on initiating a new green concept car & 3.26 & 107 & 0.883 \\
\hline Allow employees to make decisions & 3.23 & 107 & 0.721 \\
\hline Knowledge sharing regarding green technology between supervisors and subordinates & 3.21 & 107 & 0.919 \\
\hline Value employees' voices & 3.17 & 107 & 0.651 \\
\hline Behavior-based appraisal policy & 3.16 & 107 & 0.754 \\
\hline Knowledge sharing regarding green technology among colleagues & 3.10 & 107 & 0.582 \\
\hline Metrics to measure the effectiveness of innovation initiatives & 3.07 & 107 & 0.850 \\
\hline Course on innovation policies & 3.06 & 107 & 0.656 \\
\hline Programs to help in doing green innovations & 3.05 & 107 & 0.905 \\
\hline Knowledge sharing regarding green technology among departments & 3.05 & 107 & 0.817 \\
\hline Results-based appraisal policy & 2.89 & 107 & 0.839 \\
\hline Conduct surveys to compare the compensation policies fair against competitors' & 2.89 & 107 & 0.994 \\
\hline Reward for initiate, develop and implement green concepts & 2.86 & 107 & 0.829 \\
\hline Green technology programs & 2.78 & 107 & 0.769 \\
\hline Individuals' contribution in green technology implementation & 2.71 & 107 & 0.942 \\
\hline Green technology workshops for new hires & 2.65 & 107 & 0.825 \\
\hline Employees' development in applying green technology & 2.64 & 107 & 0.936 \\
\hline Programs on management of the green systems technology & 2.50 & 107 & 0.925 \\
\hline A large salary difference between high and low performers of green technology & 1.94 & 107 & 0.899 \\
\hline
\end{tabular}

\section{DISCUSSION AND IMPLICATIONS}

This research investigated the impact of strategic human resource management and knowledge management on innovativeness in green technology at the automotive industry with an emphasis on Proton's Holding Berhad, Malaysia. The strategic HR components like training, performance-based reward and team development have impacts on green technology innovation. Organizational culture serves as the mediator between the strategic HR management system and innovativeness in green technology. Moreover, knowledge management has a direct impact on the firm's green innovativeness through knowledge sharing and knowledge application. However, the framework is still open for further exploration and empirical analysis. The future possible research can be developed to explore the different effective parameters on green technology innovation in auto industry.

Today, with the rapid pace of technological changes, auto manufacturers adopt new technologies in line with the global competition. An urgent action to deal with the environmental degradation through technological innovation and dynamic knowledge would accelerate the 
flow. Thus, Proton as the leading Malaysian national car manufacturer needs to plan a deliberate strategic human resource program in order to upgrade workforces' knowledge and skills and subsequently improve green technology innovation in its new cars. The analysis in regards of the role of human resource practices and knowledge management in green innovation points out the main path to business success in the auto industry. Innovation through investment in intellectual capital could prepare Proton's talents to be sensitive and proactive to changes and competition. According to the results, strategic HR components like training, performance-based reward and team development have a positive impact on green innovations, by the mediating role of organizational culture. Furthermore, knowledge management has a direct effect on the firm's green innovativeness through knowledge sharing and knowledge application.

\section{CONCLUSION}

This study's findings offers evidence that implementation of green innovation requires more consistent focus towards quality and team development as core values. It implies that Proton's staffs require more practical and technical knowledge in green technology to enhance their productivity. Thus, transfer of technical methods and procedures work as engines for the green innovation process.

In addition, forming strong strategic alliances with engineering consultants, academic institutions and government and conducting training programs to employees who are engaged in green technology process would help Proton to boost green innovation. Dedicated and sufficient funding for green projects to ensure the strategic implementation actions happen is a necessity.

Proton needs to develop knowledge management and team development by hiring creative talents and improving training programs that bring a positive change in the employees' attitude and approach towards their job.

Implementation of green technology requires consistent focus towards quality and team development as core values. Proton's people require the practical knowledge in green technology by importing innovative technical methods and procedures. Concurrently, improving organizational culture and focus on teamwork could increase the efficiency. Focus on the key factors might serve the managers to enhance the investment on and move towards sustainable development to direct future growth.

In general, innovative manufacturing systems and technologies solitary can enhance operational performance a little, unless an appropriate HR system is in place to elicit the employees' motivation and develop their organizational expertise. Generally, to be successful, automakers must strictly align their HR strategies with environmental technology opportunities, business plans and the organization unique characteristics and distinctive competences. In a nutshell, the strategic orientation of automotive R\&D reflects the industry's mission to incorporate sustainability into the future transportation and then create a competitive advantage for the economy, contribute to social welfare and protect the ecological system.

\section{REFERENCES}

Castells, M., 1999. Information technology, globalization and social development. United Nations Research Institute for Social Development.

Chen, C.J. and J.W. Huang, 2007. Strategic human resource practices and innovation performance-the mediating role of knowledge management capacity. J. Bus. Res., 62: 104-114. DOI: 10.1016/j.jbusres.2007.11.016

Deming, W.E., 2000. Out of the Crisis. 1st Edn., MIT Press, Cambridge, ISBN-10: 0262541157, pp: 507.

Dinopoulos, E., 2006. Growth in open economies, schumpeterian models. University of Florida.

Frenken, K., M. Hekkert and P. Godfroij, 2004. R\&D portfolios in environmentally friendly automotive propulsion: Variety, competition and policy implications. Technol. Forecast. Soc. Change, 71: 485-507. DOI: 10.1016/S0040-1625(03)00010-6

Hodgetts, R.M. and K.W. Hegar, 2007. Modern Human Relations at Work. 1st Edn., Cengage Learning, Mason, ISBN-10: 0324421494, pp: 640.

Lado, A.A. and M. Wilson, 1994. Human resource systems and sustained competitive advantage: A competency-based perspective. Acad. Manage. Rev., 19: 699-727.

Laforet, S., 2007. Size, strategic and market orientation affects on innovation. J. Bus. Res., 61: 753-764. DOI: 10.1016/j.jbusres.2007.08.002

Lau, C.M. and H.Y. Ngo, 2004. The HR system, organizational culture and product innovation. Int. Bus. Rev., 13: 685-703. DOI: 10.1016/j.ibusrev.2004.08.001

McMahan, G.C., M. Virick and P.M. Wright, 1999. Alternative theoretical perspectives for strategic human resource management revisited: Progress, problems and prospects. Res. Personnel Hum. Resource Manage., 4: 99-122. 
Miller, R., 1994. Global R\&D networks and large-scale innovations: The case of the automobile industry. J. Res. Policy, 23: 27-46. DOI: 10.1016/00487333(94)90025-6

Montazeri, S.R and W. Wan, 2011. Green technology innovation in Volkswagen passat. Proceedings of the International Conference on Management, Jun. 1314, Penang, Malaysia, pp: 1335-1365.

Muffatto, M., 1998. Corporate and individual competences: How do they match the innovation process? Int. J. Technol. Manage., 15: 836-853. DOI: 10.1504/IJTM.1998.002640

Nunes, B. and D. Bennett, 2008. Green innovation management in the automotive industry. Aston University, UK.

Pollack, L.W., 1968. Legal boundaries of air pollution control-state and local legislative purpose and techniques. Duke University School of Law, Durham, NC.

Pollet, B.G., I. Staffell and J.L. Shang, 2011. Current status of hybrid, battery and fuel cell electric vehicles: From electrochemistry to market prospects. J. Electrochimica Acta, 84: 235-249. DOI: $10.1016 /$ j.electacta.2012.03.172

PHB, 2011. Proton 2011 annual report. Proton Holdings Berhad.
Remmen, A. and B. Lorentzen, 2000. Employee participation and cleaner technology: Learning processes in environmental teams. J. Cleaner Product., 8: 365-373. DOI: 10.1016/S09596526(00)00039-1

Sudin, S., 2011. Strategic green HRM: A proposed model that supports corporate environmental citizenship. Proceedings of the International Conference on Sociality and Economics Development, (SED’ 11), IACSIT Press, Singapore, pp: 79-83.

Tavakkoli-Moghaddam, R., N. Ale-Ebrahim, A. Golnam, M. Vaseil and A. Ghazizadeh-Moghaddam, 2006. Analysis of opportunities and challenges for R\&D management and the role of the R\&D society for its improvement-a case study in Iran. Proceeding of the R\&D Management Conference, Jul. 6-6, Newby Bridge, Cumbria, UK., pp: 1-7.

USEPA, 2010. Origins of modern air pollution regulations. United States Environmental Protection Agency.

ZTE, 2011. ZTE green technology innovations white paper. ZTE Corporation, Shenzhen. 